\title{
Review: Old and New in Fiji
}

Author(s): A. C. H.

Review by: A. C. H.

Source: The Geographical Journal, Vol. 33, No. 2 (Feb., 1909), pp. 203-204

Published by: geographicalj

Stable URL: http://www.jstor.org/stable/1777384

Accessed: 27-06-2016 04:06 UTC

Your use of the JSTOR archive indicates your acceptance of the Terms \& Conditions of Use, available at

http://about.jstor.org/terms

JSTOR is a not-for-profit service that helps scholars, researchers, and students discover, use, and build upon a wide range of content in a trusted digital archive. We use information technology and tools to increase productivity and facilitate new forms of scholarship. For more information about JSTOR, please contact support@jstor.org.

The Royal Geographical Society (with the Institute of British Geographers), Wiley are collaborating with JSTOR to digitize, preserve and extend access to The Geographical Journal 
range has long been called. The result was not very satisfactory. The leader, Captain de Rochemont, struck the Omba river, and followed it and its tributary, the Aru, to a distance of some 30 miles as the crow flies, east of Kiruru, the camp on Etna bay. The coolies were beyond control, spent a whole day in covering a few miles when bringing up provisions, and finally struck altogether, necessitating the return of the expedition. An elevation of 6600 feet was attained at the last camp, and several prominent points were fixed by cross-bearings. Meanwhile Heer Meyjes was engaged in observations on the coast-line. He connected his astronomical observations with those of Australia through Thursday island, and in many points rectified the former delineation of the coast-line. Pisang bay, named by Augustijn Dirks in. 1679, could not be found by Heer de Jong in 1903, and its non-existence was confirmed by this expedition. The highest peak of the Sneeuwgehergte lies in lat. $4^{\circ} 3^{\prime} 30^{\prime \prime} \mathrm{S}$. and $137^{\circ} 8^{\prime} \mathrm{E}$. long., and its height was fixed as 5100 metres (16,700 feet). There is some doubt about the Carstensz top, a little further to the north-east, the height of which was estimated by Heer Hondius van Herwerden, commander of the Valk, as not less than 5500 metres. Heer Meyjes also took part in a Government expedition up the Digóel river, which enters the sea to the north of Frederick Hendrik island, and was discovered in 1903 by De Jong. The furthest point attained was in $5^{\circ} 49^{\prime} \cdot 6 \mathrm{~S}$. lat. and $140^{\circ} 15^{\prime} \cdot 5 \mathrm{E}$. long., at a distance of about 300 miles from the coast.

The proceedings of the expedition are narrated with great detail by Heer Meyjes and Captain de Rochemont, and are well illustrated by maps and photographs. The latter half of the volume consists of reports on astronomical and hydrographic observations, geology by Heer Moerman, meteorological and anthropological observations by Dr. Koch, lists of plants and insects, etc. An ammonite, of a species not recognizable owing to its damaged condition, is of interest as the first sure proof of the existence of the Mesozoic system in the south of New Guinea.

W. A. T.

\section{Old and New in Fiji.}

'The Fijians: A Study of the Decay of Custom.' By Basil Thomson. London: W. Heinemunn. 1908. Price 108. net.

Mr. Basil Thomson is already well known as the author of several charming books on the West Pacific, and once more we are indebted to him for an admirable book on native custom and belief-this time on the Fijians, among whom he lived with short intervals for ten years, occupying important executive offices. A fair amount has already been written about these interesting people, and though $\mathrm{Mr}$. Thomson's book constitutes an important addition thereto, a good deal more has yet to be discovered and recorded. For example, Mr. Thomson reprints the clear account of the Mbau marriage system from the Journal of the Anthropological Institute (vol. 24, 1895), but from information recently received from Dr. Rivers (Nature, 1908, p. 394), we gather that this is not the only marriage system in Fiji. The Fijians are Melanesians, but the group of islands has for a long period been subject to Polynesian influence through the Tongans. "Polynesian infusion is strongest on the eastern margin of the group, and wanes with every mile we travel westward, until it is lost altogether." From 1790, if not earlier, an expedition to Fiji from Tonga was an annual occurrence; indeed, we learn that the grand tour for a Tongan gentleman included a campaign in Fiji. Mr. Thomson traces the rise of Mbau power: originally it was a humble tribe of sturdy mountain warriors of Vitilevu, who, partly through chance and partly through genius for intrigue, won its way within a century to the foremost position in the group. Mbau was at the zenith of her power in 1828 ; four years later a successful rebellion dethroned the chief, but his son Seru restored him to power in 1837. Seru's own party called him 
Thikinovu ("the centipede"), which bites without warning; the usurpers called him $\mathrm{Na} \mathrm{Mbi}$ ("the" turtle-pond "), in allusion to the number of people who were killed and eaten by him; but the name by which he was generally known was Thakombau ("destruction to Mbau," or "Mbau is undone "), signifying the success of his coup d'état. The further history of Thakombau makes interesting reading, as the coming of the white man greatly complicated that remarkable man's career. Mr. Thomson's intimate and sympathetic knowledge of the people enables him to give us much precise information that is of the utmost value to the ethnologist and sociologist, and the contents of the book range through most of their family life, sociology, and government. One feature is the amount of space devoted to endemic diseases, leprosy, yaws, and tuberculosis, all of .which are of anthropogeographical interest. The great value of the book, however, is in the clear and impartial manner in which the author traces the effects of the contact of the white man upon the Fijian. The Government official with the best intention, and the missionary from the highest motives, have made many blunders through ignorance. Any transition from barbarism to civilization is a troublesome period, which is fraught with grave danger to social and private morality. In most parts of Eurasia the evolution was very slow, and was usually effected by the contact of peoples of similar race, or, at all events, the disparity between the civilizing element and the more backward population was not very great. In the Pacific the reverse has occurred. An overweening and energetic people, obsessed with the desire of supplementing native methods of action and thought, has forced itself on the autocthones, who were in a state of low barbarism. The white man was in a hurry to effect changes, his knowledge of the local conditions was often very imperfect, and in some cases it was considered preferable to sweep away the old, rather than to let the natives gradually work out their own salvation with the aid of the new example and precept. The results in some cases were not at all what were expected. Those who have to govern native races, and those who seek to proselitize, should read this illuminating account of the conflict of the now with the old. It strongly supports the view that Government officials and missionaries should have instruction in sociology and ethnology before engaging in their several vocations.

A. C. H.

\section{POLAR REGIONS.}

\section{The Greenland Eskimo.}

'The People of the Polar North : a Record.' By Knud Rasmussen. Compiled from the Danish originals and edited by G. Herring; illustrations by Count Harald Moltke. London: Kegan Paul, Trench, Trübner \& Co. 1908. Price 21s. net.

Knud Rasmussen, 'Under Nordenvindens Sv $\phi$ be.' Copenhagen: Glydendalske Boghandel. 1906.

Knud Rasmussen has described to us in popular language his experiences among " the most northerly dwelling people in the world, an unnamed group of Greenland Eskimo" who wander from settlement to settlement between Cape York, north of Melville bay, and Cape Alexander-approximately, therefore, between $76^{\circ}$ and $78^{\circ}$ N. lat. There appears to be a tribe of " inland dwellers" who possess neither kayaks nor dogs; indeed, they are terribly afraid of the latter. It would be most interesting if more information could be obtained concerning this mysterious folk, who may wrest the honour of "the farthest north" from the kayak hunters described by the author. The book is a delightful "regional study" of conditions of existence that appear particularly unattractive to those who prefer warmer latitudes and a life of less strenuousness and privation. In picturesque language Rasmussen describes the grandeur and beauty of a desolate land, and even the 